India, which was to be completed in twenty-five years and then revised every thirty years. Sub. sequent events led to a modification of the scheme. In 1913 it was realized that the allotted time was too short, and a smaller scale of map was sanctioned for the less populous areas. But the Great War and subsequent financial stringency still further curtailed the plan. By 1935 only two-thirds of the programme had been completed. Surveys are being carried out at the rate of about thirty-nine thousand square miles a year, and if this can be maintained the programme will be completed in about sixteen years. Meantime, the maps of a large part of India, except on a small scale, are much out of date and printed mostly in black only. The Report contains a key map showing the degree of obsolescence of various sheets. Maps of India, Burma and adjacent countries on the 'one million' scale are now practically complete and the sheets of the Carte Internationale are approaching completion. A separate publication of the Survey of India is an Index to Annual Reports, 1904-5 to 1926-27.

\section{Discoveries in Antarctica}

Some valuable details of new discoveries in Antarctica accompanied by photographs are contained in an article in the National Geographic Magazine for July by Mr. L. Ellsworth on "My Flight across Antarctica". It will be remembered that in December of last year, Mr. Ellsworth reached the Bay of Whales in the Ross Sea after a flight from Dundee Island, Graham Land. This took him over an entirely unknown part of Antarctica to the Pacific side of the Pole. South of Stefansson Strait he discovered a lofty rugged mountain range with an apparent trend between north-north-west and south-south-east. Farther on, other peaks appeared, one rising to 13,000 feet. Mr. Ellsworth made several landings in about lat. $80^{\circ} \mathrm{S}$. and found a plateau at an elevation of more than 6,000 ft. He gave the names HollickKenyon plateau to this elevated country, and James W. Ellsworth Land to the whole area between Hearst Land and Marie Byrd Land. The photographs of the new mountains do not suggest the block faulted mountains of Queen Maud Ranges, but rather the Andean ranges of Graham Land which, from Admiral Byrd's recent discoveries, would seem to continue into Edward Land.

Further light on this problem is shed by an article by Mr. W. L. G. Joerg in the Geographical Review of July on "The Topographical results of Ellsworth's Trans-antaretic Flight". Mr. Joerg has mapped the direction of the new ranges as far as available data allow, and his map appears to confirm the suggestion of $R$. Staub that the axes of the Antarctic Andes of Graham Land spread fanwise in Hearst Land. Each of the newly discovered ranges seems to be a continuation of one of the three-fold lines of Graham Land. The relation of these folds to the plateau land of Antarctica has still to be determined, and Mr. Joerg's suggested direction does not continue into Edward Land. Mr. Ellsworth's photo- graphs also suggest that Stefansson Strait is narrower than previously supposed, or possibly that it is an embayment on the east of Graham Land and not a strait. Its eastern entrance lies mainly north of the seventieth parallel. The discoveries open a field for future ground exploration.

\section{Recommended Values of Illumination}

THE Illuminating Engineering Society has issued a list of the values of illuminations which are recom. mended for various purposes. It has been prepared by the Technical Committee of the Society, and copies of the full recommendations can be obtained from the Honorary Secretary, I.E.S., 32 Victoria Street, S.W.1, price $6 d$. Since the candle-powers of electric lamps are known and the distance of the lamps from the work bench can easily be estimated, it is not difficult to estimate the candle-power. The committee recommends that if the task requires both discrimination and response, the foot-candle value should be at least 50. For severe and visual tasks such as fine engraving, sewing of dark goods, and discrimination of fine details of low contrast, the foot-candle value should not be less than 25. For prolonged critical visual tasks such as proof-reading, type-setting, drawing, reading, fine machine-work, fine assembling and use in large stores, a foot-candle value between 15 and 25 is recommended. A foot-candle value of 8-15 would be suitable for visual tasks such as detailed office work, skilled bench work and sewing on light goods and for retail shops. For less-exacting visual tasks, such as general office, large assembly work and classrooms, $5-10$ suffices. For work of a simple character not involving close attention of fine details, 3-5 foot-candles is suitable. For casual observation where no specific work is performed, 2-4 foot-candles is regarded as sufficient.

\section{Streamlined Trains}

PeOPLE who have travelled in the new lightweight high-speed trains may have wondered why this new development has not come into wider use, and look forward to the time when most passenger trains will be similarly streamlined. According to a report issued by Science Service of Washington, D.C., L. K. Sillcox, the engineer of the New York Brake Company, discusses this point in a report to the American Society of Mechanical Engineers. He says that only about 20,000 route miles of the main lines of the railroads of the United States are fitted by their curves, grades and traffic to be usable for lightweight trains that can go at 100 miles an hour. This length of railway is only about ten por cent of the total mileage of railroads in the United States. It is well known that crowds will gather to see a passenger locomotive go by if it is fitted with a metal shroud that helps its streamlining or presents what the public thinks is a streamlined appearance. But this shroud adds $13,000 \mathrm{lb}$. to the weight of the locomotive. Another drawback is that the equipment has to be built very robust. Like motor-cars, the internal equipment has to be turned over and renewed every few years. In addition, any new railroad rolling stock 